\title{
On the Nonlinearity of the Financial Ratios-Credit Ratings Relationship
}

\author{
Afef Feki Krichene ${ }^{1} \&$ Walid Khoufi ${ }^{2}$ \\ ${ }^{1}$ Faculty of Economic Sciences and Management, Sfax University, Tunisia. \\ ${ }^{2}$ High Commercial Studies Institute, Sfax University, Tunisia. \\ Correspondence: Afef Feki Krichene, ‘Governance, Finance and Accounting Laboratory’_(0021620186100), Tunisia.
}

Received: March 12, 2016

doi:10.11114/afa.v2i2.1604

\author{
Accepted: April 26, 2016 \\ Available online: May 12, 2016
}

URL: http://dx.doi.org/10.11114/afa.v2i2.1604

\begin{abstract}
In this paper, we study the specificity of financial ratios in determining credit ratings. Specifically, we examine the nonlinearity of the financial ratios-credit ratings relationship.

Among financial ratios, the interest coverage and debt coverage ratios have the most pronounced effect on credit ratings. To determine the form of the nonlinearity, the interest and debt coverage ratios are divided to four sub-variables with different weights associated to each increment. We find that different coefficients are associated to different increments of the interest coverage and debt coverage ratios. An interest coverage ratio loses all significance when it is less than zero and when it exceeds 20. Similarly, a debt coverage ratio loses all significance when it less than negative one and when it exceeds one. Our results confirm the nonlinearity of the financial ratios-credit rating relationship.
\end{abstract}

Keywords: Financial ratios, credit rating, nonlinearity, increments, weights.

\section{Introduction}

Moody's and Standard and Poor's are the two major rating services for corporate debt. These services employ both public information, such as accounting statements, and nonpublic information, such as interviews with managers, to assign quality ratings to corporate bonds.

Previous research analyzes how the rating agencies use public information in setting quality ratings.

The need for reliable financial statement data and the importance of financial ratios for analysis and prediction is well established in the literature. Perhaps the major problem faced by researchers is the difficulty of using these ratios similarly to other variables.

Beginning with Blume et al (1998) contention that standard financial ratios can predict the long term issuer's credit ratings, many subsequent studies have attempted to demonstrate the predictive value of various techniques for estimating credit ratings.

Several techniques were used including multiple regression analysis (Horrigan, 1966; Pogue and Soldofsky, 1969; West, 1970), multiple discriminant analysis (Pinches and Mingo, 1973; Altman and Katz, 1976), ordered linear probit model (Kaplan and Urwitz, 1979; Poon, 2003; Cheng et al, 2009; Hwang et al, 2010), ordered and unordered linear logit models (Ederington, 1985), bayesian networks (Wijayatunga et al, 2006), support vector machines and neural networks (Huang et al., 2004).

We also find studies concerned with assigning ratings to particular bond issues (Pogue \& Soldofsky, 1969; West, 1970; Pinches \& Mingo, 1973; Blume et al., 1998). Pinches and Mingo (1973) use factor analysis to arrive at a set of six factors considered determinants of bond issues ratings: subordination, years of consecutive dividends, issue size and three financial ratios. These factors differ significantly from those considered determinants of issuer ratings defined as firms' size, financial leverage, coverage, cash flow, profitability, liquidity, market-driven variables and industry variables (Hwang et al., 2010).

By examining the determinants of bonds ratings, Blume et al. (1998) focus on the changing standards used in assigning ratings. They showed that ratings degradations' no longer reflect deterioration in their quality, but the use of stringent rating standards. They suggest that if it were not for the use of more stringent rating standards, the level of bond ratings might have actually been higher today than in the past. Another explanation of their results is that the meanings of the firm variables used to have changed over time. For example, it could be that an interest coverage of 5 ten years ago 
indicated a higher creditworthiness than the same value does today.

Nenide et al (2010) have highlighted in their study problems associated with the use of financial ratios. They identify four types of issues that should be considered and treated for the results to be useful and relevant: data entry errors, negative denominators, outlier influence and normality of distribution.

They showed that comparative ratios assume proportional numerators and denominators, the deviations from this assumption can lead to unusable ratios. A negative denominator lost a ratio any significance. A negative denominator and numerator lead to a positive ratio, but that should not be included in calculating the average. A denominator tends to zero can lead to a high ratio which skews the calculation of the average ratio.

These issues have a significant impact on our study in which we determine the credit rating from financial ratios.

Some earlier studies, like Blume et al (1998) and Gray et al (2006) have used different increments of the interest coverage ratios to determine credit ratings, but no paper has highlight the specificity of financial ratios in determining credit ratings.

The objective of this paper is to focus on the specificity of financial ratios (generally) in determining credit ratings and especially on the nonlinearity of the financial ratios-credit ratings relationship.

In a previous study (Feki et al, 2015), using an ordered probit model, we have examined the impact that various financial and business profile variables have on credit ratings issued for the S\&P 500 index firms by Moody. The results indicate that firms' financial policy, size and liquidity are significant but interest coverage and debt coverage ratios have the most pronounced effect on credit ratings.

The ordered probit approach models credit ratings as depending on a linear function of the independent variables. In results not presented in this paper, we find that some of the explanatory variables are highly skewed. In particular, there are a number of extreme outliers in the interest and debt coverage variables caused primarily by companies with very small amounts of debt, a standard low-denominator problem. In addition, the interest coverage ratio can be negative when earnings are negative. The magnitude of the interest coverage ratio may not be meaningful for observations with a small interest expense and large negative earnings. To highlight the problem at hand, according to S\&P's criteria, an increase in EBIT interest coverage from 2 to 6 would be considered significant, and potentially lead to an upgrade from BB to A, other things equal. In contrast, an increase from 96 to 100 would carry little significance and is unlikely to have any effect on a firm already rated AAA. Debt coverage variables are also plagued by extreme observations. A debt coverage ratio of one indicates coverage of one hundred percent, which is indicative of an AAA-rated issuer. Increments beyond one indicate the firm's cash flows are more than sufficient to cover the entire amount of debt on issue. Extreme debt coverage observations skew the sample. For example, a debt coverage ratio of 19 and 13 times, will not add any additional information and misrepresents the real financial position.

As a result, the assumption of a linear relationship between the financial ratios and the credit rating may be violated for these variables. Therefore, empirical corrections are necessary for the interest coverage and debt coverage variables, to overcome these limitations.

The reminder of this paper is as follows. Section 2 details the methodology: sample, data and variables measures. The main results are discussed in section 3 and the conclusion in section 4 .

\section{Methodology}

\subsection{Sample and Data}

Our initial sample consists of American companies that belong to the S\&P500 index. Historical long-term issuer credit ratings are obtained through the Moody's Ratings website. Ratios and financial information for the period 2008 to 2010 are collected from Thomson Reuters Datastream (Worldscope Base). Financial firms are excluded from the sample due to significant differences in accounting standards and rating methodologies.

Also, companies rated $\mathrm{Caa} 1, \mathrm{Caa} 2$ and $\mathrm{Ca}$ are removed from the sample because of their minority compared to the total sample. The total number of firms that meet the above criteria is 315 . Figure 1 provides the distribution of our sample by ratings. Most observations are clustered in the A and Baa categories (more than 60\%). While the Aaa, Aa and B categories cover near $40 \%$ of our sample, the Caa and Ca categories form a minority. 


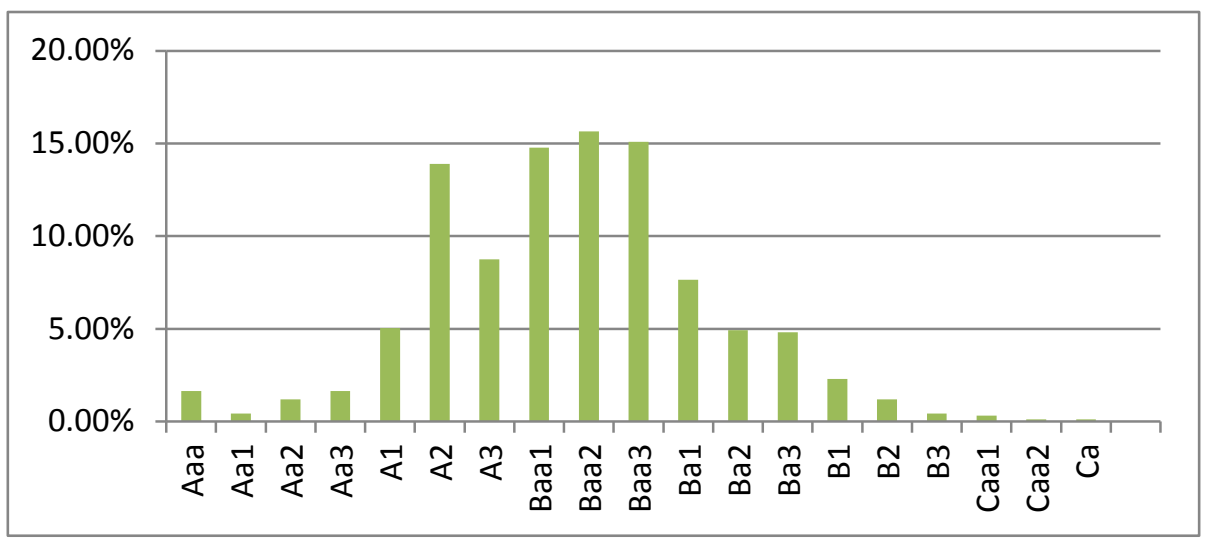

Figure 1. Distribution of Sample Observations by Ratings

Results would concern only the interest coverage and debt coverage ratios in determining credit ratings. The interest coverage ratio, measured by the EBITDA relative to interests, is likely to have higher credit rating. Debt coverage ratios, such as free cash flow or funds from operations relative to total debts, lead also to higher credit ratings.

In this paper, we seek to relate financial ratios to credit ratings. The approach adopted is the ordered probit model.

This method is designed for studies in which the dependent variable takes a finite number of values that possess a natural ordering. We develop five ordered rating classes: Aaa/Aa1/Aa2/Aa3, A1/A2/A3, Baa1/Baa2/Baa3, Ba1/Ba2/Ba3 and $\mathrm{B} 1 / \mathrm{B} 2 / \mathrm{B} 3$.

The dependent variable, the credit rating of company $\mathrm{i}$ in a year $\mathrm{t}, \mathrm{Y}_{\mathrm{it}}$, takes 1 if the company is rated B1, B2 or B3, 2 if the company is rated $\mathrm{Ba} 1, \mathrm{Ba} 2$ or $\mathrm{Ba} 3,3$ if the company is rated $\mathrm{Baa} 1, \mathrm{Baa} 2$ or $\mathrm{Baa} 3,4$ if the company is rated $\mathrm{A} 1, \mathrm{~A} 2$, or $\mathrm{A} 3$ and 5 if it is rated Aaa, Aa1, Aa2 or Aa3.

\subsection{Correction of the interest coverage ratio}

By introducing the interest coverage ratio as a determinant of the long-term credit rating, we found that this variable has a negative effect on the rating; which is wrong and not consistent with the theory. Theoretically, firms having higher interest coverage ratios benefit from higher ratings. To correct this, each negative observation is replaced by zero. In addition, each observation over 100, is replaced by 100; assuming that any increase beyond 100 provides no additional information.

By introducing this variable as the sum of four sub-variables, each increment has a different weight and sign. So, we change the specification of the model, to determine the form of the non-linearity. Specifically, the interest coverage variable is introduced, in the model, as the sum of the four sub-variables $\mathrm{C}_{1 \mathrm{it}}, \mathrm{C}_{2 \mathrm{it}}, \mathrm{C}_{3 \mathrm{it}}$ and $\mathrm{C}_{4 \mathrm{it}}$ as described in the following equation:

$$
\sum_{\mathrm{j}=1}^{4} \mathrm{Kj} \mathrm{Cjit}
$$

Where $\mathrm{j}$ denotes the index of the sub-variable that takes the values 1,2,3 or 4, Cit denotes the interest coverage ratio for firm $\mathrm{i}$ in year $\mathrm{t}$, and $\mathrm{Kj}$ denotes the coefficients associated to sub-variables Cjit. Cjit is defined as follows:

\begin{tabular}{lllll} 
& $\mathbf{C}_{\text {1it }}$ & $\mathbf{C}_{2 i \mathrm{t}}$ & $\mathbf{C}_{3 \mathrm{it}}$ & $\mathbf{C}_{4 \mathrm{it}}$ \\
\hline $\mathbf{C}_{\mathrm{it}} \in[\mathbf{0 , 5 )}$ & $\mathrm{C}_{\mathrm{it}}$ & 0 & 0 & 0 \\
$\mathbf{C}_{\mathrm{it}} \in[\mathbf{5 , 1 0 )}$ & 5 & $\mathrm{C}_{\mathrm{it}}-5$ & 0 & 0 \\
$\mathbf{C}_{\mathrm{it}} \in[\mathbf{1 0 , 2 0 )}$ & 5 & 5 & $\mathrm{C}_{\mathrm{it}}-10$ & 0 \\
$\mathbf{C}_{\mathrm{it}} \in[\mathbf{2 0 , 1 0 0 )}$ & 5 & 5 & 10 & $\mathrm{C}_{\mathrm{it}}-20$ \\
\hline
\end{tabular}

This specification assigns different weights for each increment of the interest coverage ratio. Blume et al (1998) support 
the use of this specification as they found, in their sample, that an increase of this ratio from 3 to 6 , may lead to an increase of the rating, while a change from 97 to 100 , has probably no effect on the rating. If this is true, Kj associated with large values of this ratio should be close to zero.

\subsection{Correction of the debt coverage ratio}

A debt coverage ratio of one indicate coverage of one hundred percent, which is indicative of a better class rating (AAA). Increments beyond one state that the firm's cash flows are more than sufficient to cover the entire amount of debt. Negative and positive extremes, are less likely to be informative. A high ratio could be the result of a low level of debt financing relative to previous years combined with a stronger than historical cash flow (Gray et al, 2006). For this reason, observations of the cash flow and operating funds debt coverage ratios greater than five are set equal to five and those less than negative one are set to negative one.

We make assumptions that different coefficients are associated with different increments of the debt coverage ratios: L1 for the increment from negative one to zero, L2, for the increment from zero to 1, L3, for the increment from one to 3 and L4 for the increment from 3 to 5.

The debt coverage ratio is presented as the sum of the four sub-variables $\mathrm{D}_{1 \mathrm{it}}, \mathrm{D}_{2 \mathrm{it}}, \mathrm{D}_{3 \mathrm{it}}$ and $\mathrm{D}_{4 \mathrm{it}}$ according to the following equation:

$$
\sum_{j=1}^{4} \mathrm{Lj} \text { Djit }
$$

Where $\mathrm{j}$ denotes the index of the sub-variable that takes the values $1,2,3$ or 4 , Dit denotes the debt coverage ratio for firm $\mathrm{i}$ in year $\mathrm{t}$, and $\mathrm{Lj}$ denotes the coefficients associated to sub-variables Djit.

Djit is defined as follows:

\begin{tabular}{|c|c|c|c|c|}
\hline & $\mathbf{D}_{\text {1it }}$ & $\mathbf{D}_{2 \mathrm{it}}$ & $\mathbf{D}_{3 \mathrm{it}}$ & $\mathbf{D}_{4 \mathrm{it}}$ \\
\hline $\mathbf{D}_{\mathrm{it}} \in[-\mathbf{- 1}, \mathbf{0})$ & $\mathrm{D}_{\mathrm{it}}+1$ & 0 & 0 & 0 \\
\hline $\mathbf{D}_{\mathrm{it}} \in[\mathbf{0}, \mathbf{1})$ & 0 & $\mathrm{D}_{\mathrm{it}}$ & 0 & 0 \\
\hline$D_{i t} \in[1,3)$ & 0 & 1 & $\mathrm{D}_{\mathrm{it}}-1$ & 0 \\
\hline $\mathbf{D}_{\mathrm{it}} \in[\mathbf{3}, \mathbf{5})$ & 0 & 1 & 2 & $\mathrm{D}_{\mathrm{it}}-3$ \\
\hline
\end{tabular}

\section{Results}

Table 1. The results of the ordered probit model

\begin{tabular}{cccc}
\hline & Coefficient & Standard Error & p-value \\
\hline Interest Coverage Ratio & & & \\
$\mathrm{K}_{1}$ & 0,1764 & 0,0632 & 0,001 \\
$\mathrm{~K}_{2}$ & 0,0156 & 0,0371 & 0,015 \\
$\mathrm{~K}_{3}$ & 0,0065 & 0,0183 & 0,067 \\
$\mathrm{~K}_{4}$ & $-0,0119$ & 0,0043 & 0,438 \\
Debt Coverage Ratio & & & \\
$\mathrm{L}_{1}$ & $-0,4314$ & 0,1572 & 0,044 \\
$\mathrm{~L}_{2}$ & $-0,4245$ & 0,2045 & 0,079 \\
$\mathrm{~L}_{3}$ & $-0,1278$ & 0,2398 & 0,503 \\
$\mathrm{~L}_{4}$ & 0,0502 & 0,2376 & 0,689 \\
\end{tabular}

The results presented in Table 1 show that different coefficients and signs are associated to the different increments of financial ratios.

The coefficient on the increment of the interest coverage ratio from 0 to $5, \mathrm{~K} 1$, is positive and large and differs significantly from zero. The coefficients on the increments of the interest coverage ratio from 5 to 10 , K2, and from 10 to $20, \mathrm{~K} 3$, are positive and small but differ significantly from zero. The coefficient on the increment above 20 , K4, is 
not significantly different from zero.

Thus, higher interest coverage ratios are associated with higher credit ratings. Nevertheless, when it exceeds 20 , the interest coverage ratio no longer reflects higher credit ratings.

In addition, the coefficients on the increments of the interest coverage ratio are more significant for small values of this ratio.

We find also that different coefficients are associated with different increments of the debt coverage ratio 'FCF/TDaver'. As expected, the coefficients on the increments from $(-1)$ to $0, \mathrm{~L} 1$, and from 0 to $1, \mathrm{~L} 2$, are negative, large and differ significantly from zero. While, the coefficients on the increments from 1 to $3, \mathrm{~L} 3$, and from 3 to 5 , L4, are insignifiant. This seems logical that debt coverage ratios greater than one does not reflect great capacity to cover debts. Instead, these ratios are the result of large numerators associated with small denominators due to special circumstances that do not reflect the company real situation.

\section{Conclusion}

To conclude, debt coverage and interest coverage ratios are the most pronounced determinants of credit ratings. Nevertheless, these ratios can't be used as ordinary variables depending of the credit ratings as a linear function.

An interest coverage ratio loses all significance when it is less than zero and when it exceeds 20. Similarly, a debt coverage ratio loses all significance when it less than negative one and when it exceeds one.

(To conclude) High interest coverage and debt coverage ratios don't reflect better performed firms. When they exceed certain level, financial ratios lose any significance. The effect of these ratios on credit ratings is not linear. It changes with the increments of these ratios.

The results support the specificity of ratios in determining credit rating. This specificity is materialized by the shape of non-linearity.

These results are very useful for researchers in the field of credit ratings. Financial ratios can't be used as other determinants of credit ratings. Different weights are assigned to the different increments of the financial ratio. Our results are also useful to the rating agencies. The specificity of the financial ratios and the nonlinearity of relationship must be considered.

\section{References}

Altman, E., \& Katz, S. (1976). Statistical bond rating classification using financial and accounting data. In M. Schiff and G. Sorter, eds. Topical Research in Accounting, NYU Press, New York.

Blume, M. E., Lim, F., \& Mackinlay, C. (1998). The declining credit quality of U.S. corporate debt: Myth or reality? The Journal of Finance, 53, 1389-1413. http://dx.doi.org/10.1111/0022-1082.00057.

Cheng, K. F., Hwang, R. C., \& Lee, C. F. (2009). On multiple-class prediction of issuer credit ratings. Applied Stochastic Models in Business and Industry, 25, 535-550. http://dx.doi.org/10.1002/asmb.735.

Ederington, L. H. (1985). Classification models and bond ratings. The Financial Review, 20, 237-261, http://dx.doi.org/10.1111/j.1540-6288.1985.tb00306.x.

Feki, A. (2014). Les entreprises ciblent-elles une note de credit ou un niveau d'endettement ? Etude des déterminants de la notation financière à long terme et de la structure du capital des entreprises de l'indice S\&P 500. Doctoral Thesis in Accounting and Finance, Directed by Professor Khoufi W., Faculty of Economic Sciences and Management of Sfax-Tunisia.

Feki, A., \& Khoufi, W. (2015). The determinants of issuers' long term credit ratings: American S\&P500 index. International Journal of Accounting and Economics Studies, 3(1), 78-85. http://dx.doi.org/10.14419/ijaes.v3i1.4631

Gray, S., Mirkovic, A., \& Ragunathan, V. (2006). The determinants of credit ratings: Australian evidence. Australian journal of management, 31(2), 333-354. http://dx.doi.org/10.1177/031289620603100208.

Horrigan, J. O. (1966). The determination of long-term credit standing with financial ratios. Journal of Accounting Research, 4, 44-62. http://dx.doi.org/10.2307/2490168.

Huang, Z., Chen, H., Hsu, C. J., Chen, W. H., \& Wu, S. (2004). Credit rating analysis with support vector machines and neural networks: a market comparative study. Decision Support Systems, 37, 543-558. http://dx.doi.org/10.1016/S0167-9236(03)00086-1.

Hwang, R. C., Chung, H., \& Chu, C. K. (2010). Predicting issuer credit ratings using a semiparametric method. Journal of Empirical Finance, 17, 120-137. http://dx.doi.org/10.1016/j.jempfin.2009.07.007. 
Kaplan, R., \& Urwitz, G. (1979). Statistical models of bond ratings: A methodological inquiry. Journal of Business, 52, 231-261. http://dx.doi.org/10.1086/296045.

Najjar, N. J. (2013). Can financial ratios reliably measure the performance of banks in Bahrain ? International Journal of Economics and Finance, 5(3), 152-163. http://dx.doi.org/10.5539/ijef.v5n3p152.

Nenide, B., Pricer, R. W., \& Camp, S. M. (2010). The use of financial ratios for research : Problems associated with and recommandations for using large databases. http://www.fintel.us/download/Problems with and Recommendations for Large Databases.pdf.

Pinches, G., \& Mingo, K. (1973). A multivariate analysis of industrial bond ratings. The Journal of Finance, $28,1-18$. http://dx.doi.org/10.2307/2978164.

Pogue, T. F., \& Soldofsky, R. M. (1969). What's in a bond rating? Journal of Financial and Quantitative Analysis, 4, 201-228. http://dx.doi.org/10.2307/2329840.

Poon, W. P. H. (2003). Are unsolicited credit ratings biased downward? Journal of Banking and Finance, 27, 593-614. http://dx.doi.org/10.1016/S0378-4266(01)00253-9.

West, R. (1970). An alternative approach predicting corporate bond ratings. Journal of Accounting Research, 7, $118-127$. http://dx.doi.org/10.2307/2674717.

Wijayatunga, P., Mase, S., \& Nakamura, M. (2006). Appraisal of companies with Bayesian networks. International Journal of Business, 1(3), 329-346. http://dx.doi.org/10.1504/IJBIDM.2006.009138.

\section{(cc) EY}

This work is licensed under a Creative Commons Attribution 3.0 License. 